\title{
Circulating progesterone concentrations and ovarian functional anatomy in the African elephant (Loxodonta africana)
}

\author{
D. J. de Villiers, J. D. Skinner and A. J. Hall-Martin* \\ Mammal Research Institute, University of Pretoria, Pretoria 0002, South Africa; and *Department \\ of Research and Information, National Parks Board of Trustees, Private Bag X402, Skukuza 1350, \\ South Africa
}

\begin{abstract}
Summary. Mean plasma progesterone concentrations measured in pregnant and nonpregnant elephants did not differ significantly from each other because of considerable variation, particularly for stage of pregnancy. Maximum progesterone values were recorded during early pregnancy (5-8 months) and declined towards term ( 22 months). The numbers of corpora lutea or total luteal tissue volume were not critical in maintaining progesterone secretion. An increase in plasma progesterone concentrations with the luteal phase of the ovarian cycle was evident. A possible role of the placenta in the second half of gestation is indicated by an increase in fetal progesterone concentrations towards term.
\end{abstract}

Keyuords: elephant; ovarian anatomy; pregnancy; progesterone

\section{Introduction}

Studies have been carried out on corpora lutea (CL) of African elephants (Loxodonta africana); progesterone concentrations were found to be very low in CL and only minute quantities of progesterone could be measured in peripheral plasma by early investigators (Short \& Buss, 1965; Short, 1966; Smith et al., 1969; Hanks \& Short, 1972). Therefore, CL were reported to have a significant but limited secretory capacity for progesterone (Smith et al., 1969; Ogle et al., 1973).

Plotka et al. (1975) reported a modest increase in plasma progesterone concentrations during pregnancy. This was confirmed by McNeilly et al. (1983) who detected significantly higher progesterone concentrations during pregnancy with considerable overlap in values between pregnant and non-pregnant elephants.

In the present study we examined in some detail the macroscopic anatomy of ovaries of pregnant and non-pregnant African elephants at different stages of reproduction. Relationships between ovarian structures and circulating concentrations of progesterone in maternal and fetal plasma were investigated as well as fluctuations during the ovarian cycle.

\section{Materials and Methods}

Animals. Plasma samples were collected between 13:00 and 16:00 h from family groups of elephants culled in the Kruger National Park, South Africa. Heparinized blood samples, taken peripherally shortly after the elephants were killed, were centrifuged within $2 \mathrm{~h}$ after collection. The plasma was removed and then stored at $-20^{\circ} \mathrm{C}$ until assayed.

In the field the uteri and ovaries of elephant cows were examined and weights and measurements of embryos and fetuses were recorded. Data were collected from elephants at different stages of reproduction and, following Laws \& Parker (1968), elephant cows were classified as: (i) immature when their ovaries contained no large follicles, CL, or corpora albicantia; (ii) pubertal when no CL or corpora albicantia were present but at least 1 follicle $>5 \mathrm{~mm}$ diameter was seen; and (iii) mature, when at least I CL or corpus albicans was present in the ovaries. Fetuses were weighed 
using an appropriate spring balance. Very small fetuses were returned to the laboratory for weighing the same day. Heparinized blood samples were collected from fetuses by cardiac puncture and fetal ages were determined by the revised method of Craig (1984).

Ovaries of pregnant and non-pregnant elephants were trimmed of mesentery, weighed and the maximum diameter of each $\mathrm{CL}$ was measured to the nearest $0.5 \mathrm{~mm}$ with a vernier caliper. Each ovary was sliced into 3-mm sections and Graafian follicles, small CL, including accessory $\mathrm{CL}$, and corpora albicantia were identified, counted and measured. A CL was considered to be the yellow structure that forms after ovulation (Smith \& Buss, 1975). Ovulation stigmata could be seen after recent ovulations. Volume of luteal tissue was estimated by means of the formulae for volumes of spherical and ovoid bodies, depending on their shape, respectively.

Elephants with only $C L$ present in the ovaries were assigned to the luteal phase and those with various numbers of small follicles and at least one Graafian follicle (8-20 mm diameter), but no CL, to the follicular phase of the cycle.

Age determination to the nearest year was based on the replacement of molar teeth in the lower jaw (Laws, 1966).

Student's $t$-test was used in tests of significance at a $1 \%$ level of confidence.

Radioimmunoassay of progesterone. The procedure was similar, with minor modifications, to that of Haresign et al. (1975) and Van Aarde (1985). Duplicate plasma samples $(0.1 \mathrm{ml})$ were extracted with $2.0 \mathrm{ml}$ petroleum ether (Saarchem. (Pty) Ltd, Krugersdorp, South Africa). Standards ranging from 3.9 to $1000 \mathrm{pg}$ progesterone $\left(\Delta^{4}-\right.$ pregnene-3,20-dione; Sigma Chemical Co., Poole, Dorset, UK) in ethanol were prepared in duplicate and included in each assay. Antiserum (Department of Chemical Pathology, University of Cape Town, Cape Town, South Africa) in phosphate buffer $\left(0^{-} \mathrm{I} \mathrm{ml}\right)$ at a dilution of 1:8000 was added to standards, reagent blanks and plasma extracts. The mixture in each tube was incubated at room temperature $\left(23-25^{\circ} \mathrm{C}\right)$ for $10 \mathrm{~min}$ and, after the addition of $0.1 \mathrm{ml}$ ( 10000 c.p.m.) $\left[1,2,6,7-{ }^{3} \mathrm{H}\right]$ progesterone (Radiochemical Centre, Amersham, Bucks, UK) in phosphate buffer, the contents of the tubes were mixed for $1 \mathrm{~min}$ on a vortex mixer and incubated at $4^{\circ} \mathrm{C}$ for at least $12 \mathrm{~h}$ (usually overnight). The separation of antibody-bound and free steroid was carried out at $4^{\circ} \mathrm{C}$ by adding $0.8 \mathrm{ml}$ dextran-coated charcoal consisting of a suspension of charcoal (Activole, Merck, Darmstadt, FRG) in phosphate buffer $(0.156 \mathrm{~g} / 100 \mathrm{ml})$ containing 0.0156 g Dextran T-40 (Pharmacia, Uppsala, Sweden) to the contents of each tube. Extraction efficiency and the original volume of plasma extracted were taken into account when calculating the concentrations of progesterone in plasma samples.

Validation. The antiserum specificity was described by the supplier and cross-reactions with other steroids were: pregnenolene, $1.9 \% ; 17$-hydroxyprogesterone, $2.8 \% ; 11$-hydroxyprogesterone, $24.9 \% ; 5$-pregnane-3,20-dione, $21.7 \%$; 20ß-hydroxy-4-pregnane-3-one, $0.3 \%$; 11-deoxycorticosterone, 2.1\%; 11-deoxycortisol, 1.6\%; cortisol, $<0.1 \%$; testosterone, 4-androstenedione, $17 \alpha$-oestradiol and oestrone, $<0.001 \%$. The antiserum (identification number 1521) was raised in a rabbit against progesterone-21-bovine serum albumin. Sensitivity of the assays, defined as twice the standard deviation of biank values, ranged from 4.2 to $16 \mathrm{pg} / \mathrm{ml}$ (mean $11 \cdot 1 \pm 5.0 \mathrm{pg} / \mathrm{ml} ; n=4$ ). Buffer blanks included in the assays contained less than $11.1 \mathrm{pg}$ progesterone equiv./ml. Recovery of known amounts of unlabelled progesterone $(250,500$ and $1000 \mathrm{pg} / \mathrm{ml})$ did not differ significantly from expected values and dilution curves were parallel to the respective standards. Recovery of $\left[{ }^{3} \mathrm{H}\right]$ progesterone from plasma varied from $80 \cdot 2$ to $91.9 \%$ (mean $85.3 \pm 4.3 \% ; n=4)$. Intra- and interassay coefficients of variation were 9.8 and $9.7 \%$ respectively.

\section{Results}

\section{Progesterone}

Circulating concentrations of progesterone (Fig. 1) in pregnant elephants ranged from 75 to $1331 \mathrm{pg} / \mathrm{ml}(664.5 \pm 341.6 \mathrm{pg} / \mathrm{ml} ; \mathrm{N}=44)$ and did not differ significantly $(t=1.41 ; \mathrm{d} . \mathrm{f} .=65$; $P>0.01$ ) from the values for non-pregnant elephants (range $212-1283 \mathrm{pg} / \mathrm{ml} ; 771 \cdot 3 \pm 268 \cdot 1 \mathrm{pg} / \mathrm{ml}$; $\mathrm{N}=23$ ).

During the first half of pregnancy progesterone concentration $(830 \cdot 8 \pm 299 \cdot 1 \mathrm{pg} / \mathrm{ml} ; \mathrm{N}=22)$ did differ significantly $(t=3.71 ;$ d.f. $=42 ; P<0.01)$ from that during the second half $(497.7 \pm 296.9 \mathrm{pg} / \mathrm{ml} ; \mathrm{N}=22)$, there being a gradual decline towards term (Fig. 1). No consistent relationship existed between luteal tissue volume and circulating plasma progesterone concentration (Fig. 2) in pregnant or non-pregnant cows.

Fetal plasma progesterone concentrations averaged $1148 \cdot 8 \pm 487 \cdot 1 \mathrm{pg} / \mathrm{ml}(\mathrm{N}=12)$ and increased with gestation age, while maternal values decreased (Fig. 3). During the first 14-15 months of gestation there was a significant positive correlation between maternal and fetal plasma progesterone concentrations (Pearson $r=0.96$; Spearman $r=1.00 ; N=5$ ) (Walpole \& Myers, 1985). Values were not related during the last third of gestation (Pearson $r=-0.053$; Spearman $r=-0.288 ; \mathrm{N}=7$ ). The correlation throughout gestation was not significant (Pearson $r=-0.098$; Spearman $r=-0.137 ; \mathrm{N}=12$ ). 

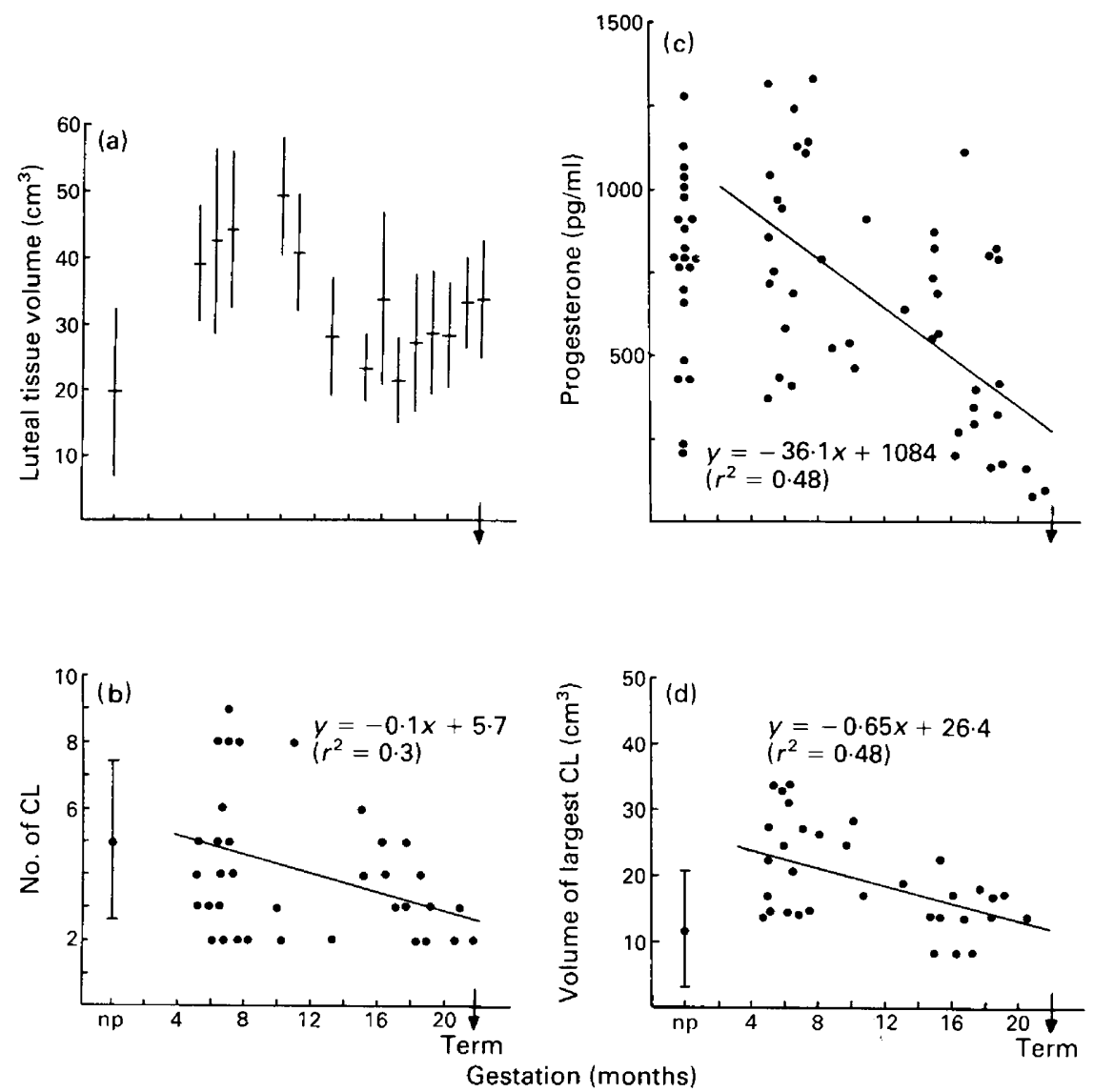

Fig. 1. The relationships between (a) total luteal tissue volume; (b) number of CL in maternal ovaries; (c) circulating maternal plasma progesterone concentration; and (d) volume of the largest single CL and gestation time in pregnant elephants. Values for non-pregnant (np) elephants are also presented.

In 2 of the 4 mature non-pregnant elephant cows with high plasma progesterone concentrations the ovaries had one developing follicle in the late follicular growth phase $(\sim 15 \mathrm{~mm}$ in diameter) and in another 2 cows the ovaries had 3 and 4 developing follicles ( $\sim 8 \mathrm{~mm}$ in diameter) respectively. Progesterone concentration in these cows $(1083 \pm 144 \mathrm{pg} / \mathrm{ml} ; \mathrm{N}=4)$ was significantly higher than that for non-pregnant cows $(t=3.42$; d.f. $=25)$. Progesterone concentration in non-pregnant females in the luteal phase (only CL present in the ovaries) was high $(808.2 \pm 44.4 \mathrm{pg} / \mathrm{ml}$; range $779-887 \mathrm{pg} / \mathrm{ml} ; \mathrm{N}=8$ ) and did differ significantly $(t=3.81$; d.f. $=12 ; P<0.01)$ from that of mature lactating cows with only corpora albicantia present in the ovaries $(435.0 \pm 216.0 \mathrm{pg} / \mathrm{ml}$; range $221-653 \mathrm{pg} / \mathrm{ml} ; \mathrm{N}=5$ ). Plasma progesterone concentration in non-pregnant cows $(951.7 \pm 135 \cdot 1 \mathrm{pg} / \mathrm{ml})$ with $\mathrm{CL}$ and corpora albicantia present in the ovaries did not differ significantly $(t=2 \cdot 26$; d.f. $=9)$ from that of mature cows with only CL present in the ovaries.

\section{Ovarian morphology}

During pregnancy the number of $C L(5 \cdot 0 \pm 2 \cdot 4 ; N=18)$ counted in young elephant cows $(<20$ years) did not differ significantly $(t=2 \cdot 48)$ from that in older cows ( $>20$ years) $(3 \cdot 4 \pm 1 \cdot 5$; $\mathrm{N}=24)$. Volume of luteal tissue in young ( $<20$ years) pregnant cows $\left(36 \cdot 3 \pm 12 \cdot 2 \mathrm{~cm}^{3} ; \mathrm{N}=9\right)$ did not differ significantly $(t=0 \cdot 65)$ from that of cows aged $>20$ years $\left(32 \cdot 8 \pm 11.9 \mathrm{~cm}^{3} ; \mathrm{N}=13\right)$. 

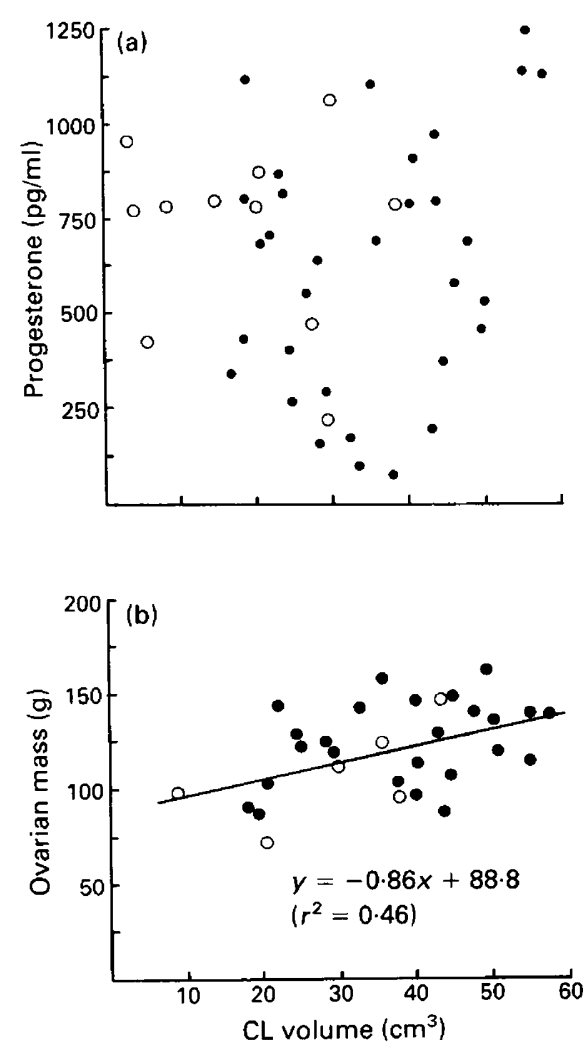

Fig. 2. The relationships between (a) circulating concentration of progesterone in plasma; and (b) ovarian mass in pregnant $(O)$ and non-pregnant $(O)$ elephants and total $C L$ volume.

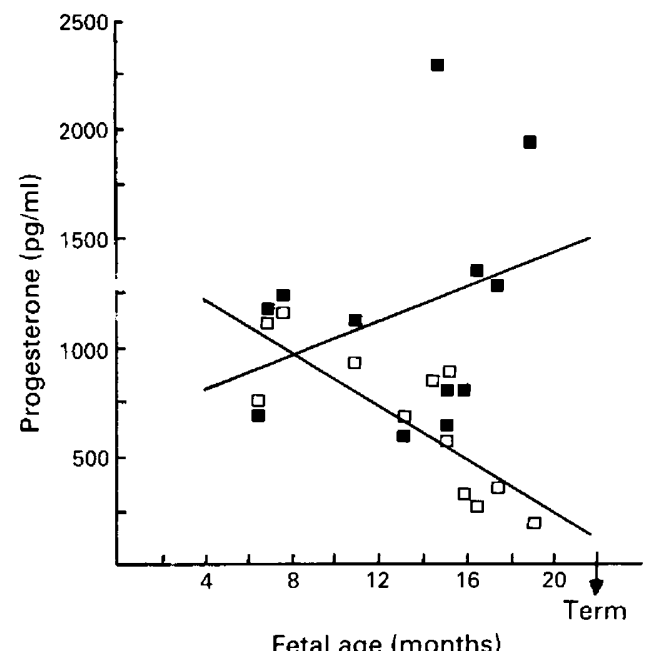

Fig. 3. The relationship between maternal ( $\square$ ) and fetal ( $\square$ ) plasma progesterone concentration with fetal age. Lines were fitted through linear regression analysis for maternal $\left(y=-60 \cdot 9 x+1458 ; r^{2}=0.79\right)$ and fetal plasma $\left(y=37.4 x+657 ; r^{2}=0.31\right)$. 
The number of corpora lutea $(4 \cdot 4 \pm 2.3$ and $4.8 \pm 2 \cdot 4$ /female) was not related to luteal tissue volume $\left(36.7 \pm 12.3\right.$ and $18.9 \pm 13.4 \mathrm{~cm}^{3} /$ female $)$ in pregnant $(\mathrm{N}=40)$ or in non-pregnant $(\mathrm{N}=16)$ cows, respectively. Corpora lutea were present throughout pregnancy and new ovulations did not occur during pregnancy. There was a slight decrease in total luteal tissue volume and number in relation to gestation period (Fig. 1). No mature non-pregnant cows with only corpora albicantia present in the ovaries were collected.

The increase in volume of $\mathrm{CL}$ was associated with increased ovarian mass in pregnant and nonpregnant elephants (Fig. 2). The mean volume of CL on the side of implantation was significantly greater $(t=2 \cdot 53$; d.f. $=62)$. Left and right ovaries did not differ significantly in weight (paired $t=0 \cdot 06 ;$ d.f. $=78$ ) and nor did weight differ significantly between those from the side of implantation and the contralateral side $(t=2 \cdot 4$; d.f. $=48)$.

During the first half of gestation CL volume $\left(43.1 \pm 10.9 \mathrm{~cm}^{3}\right)$ was significantly greater $(t=4.88$; d.f. $=37)$ than during the second half $\left(28.4 \pm 7.9 \mathrm{~cm}^{3}\right)$. For pregnant cows luteal volume $\left(36 \cdot 7 \pm 12 \cdot 3 \mathrm{~cm}^{3}\right)$ was significantly greater $(t=4.63$; d.f. $=37)$ than for non-pregnant cows $\left(19 \cdot 7 \pm 12 \cdot 8 \mathrm{~cm}^{3}\right)($ Fig. 1$)$.

\section{Discussion}

In the present study no clear distinction between plasma progesterone concentrations in pregnant and non-pregnant elephant cows could be found because of the variation, particularly for stage of pregnancy. Progesterone concentration increased during early pregnancy (5-8 months) and values during the first half of gestation were significantly higher than during the second half. This is at variance with the results of McNeilly et al. (1983) who found progesterone concentrations in pregnant elephant cows to be significantly greater than in non-pregnant cows, with maximum levels occurring at mid-pregnancy (9-12 months).

This difference is probably due to an error that Craig (1984) points out in the published formula (Huggett \& Widdas, 1951) for calculating date of conception from fetal mass for elephants used by McNeilly et al. (1983). The accepted formula for the African elephant based on the Huggett \& Widdas (1951) equation was first formulated by Perry (1953) and has been in use ever since. The revised method of Craig (1984) was used in the present study to determine fetal age; this indicates a longer early phase of slow growth until followed by an increased exponential faster growth rate. In the present study the formula, $t=106 w^{1 / 3}+138$, proposed by Craig (1984) was used, where $t$ is the fetal age and $w$ the fetal mass. In this revised equation the estimate of $t_{0}$ has been increased to 138 days from 66 days in the Huggett \& Widdas (1951) equation. The initial growth rate of small elephant fetuses is slow and possibly deviates from a linear growth relationship (Craig, 1984). To get young fetal ages of less than 140 days with the above formula, weights of less than $6 \mathrm{~g}$ are necessary.

Corpora lutea were retained throughout gestation and ovaries in all pregnant females contained more than one luteal body (mean $=4.4 \pm 2 \cdot 3 ; \mathrm{N}=40$ ). The decline in $\mathrm{CL}$ volume, decline in largest follicular size and no stigmata of recent ovulations in pregnant animals indicate that there is no replacement or augmentation of corpora lutea during pregnancy. Accessory corpora lutea were present in one pregnant female with a $6 \cdot 5$-month-old fetus and a follicle, $20 \mathrm{~mm}$ in diameter, was found.

There is no increase in number of corpora albicantia with gestation (Smith \& Buss, 1975) and these stuctures persist for about 77 months in the ovary, often into the next pregnancy (Buss \& Smith, 1966). Regression of corpora lutea is very slow and explains why no significant decline in CL number was found but only in volume and largest follicle size. Regressing CL occurred in pregnant females and in $68.3 \%$ of the ovaries examined corpora albicantia were present. No evidence for the formation of supplementary corpora lutea was found.

McNeilly et al. (1983) suggested a possible increase in progesterone concentration in relation to an increase in CL number in the ovaries of elephants. On the other hand, Hanks \& Short (1972) 
suggested that a critical mass of luteal tissue needs to accumulate before conception can occur since in their study very little progesterone was secreted by corpora lutea. The present study indicated that neither number nor total CL volume is critical to maintain progesterone secretion; it is suggested that secretory activity of one or more $\mathrm{CL}$ play an important role in progesterone secretion.

Progesterone concentration appears to be reflected by lutein cell size in a general way; CL with the largest luteal cells have higher progesterone concentrations and those with lower steroid levels contained the smallest luteal cells (Ogle et al., 1973). Luteal progesterone concentration and cell size increase during early pregnancy, peaking during the 3rd month after which there is a decline, reaching a nadir during the last 3 months (Ogle et al., 1973). Buss \& Smith (1966) presented histological evidence which indicated a reduction in luteal function with most steroidogenic activity between 2 and 14 months of gestation (using the equation of Huggett \& Widdas, 1951). This agrees with the present data which indicate a decline in progesterone concentration and CL volume in the 2nd half of gestation towards term.

The poor relationship between circulating plasma progesterone concentrations and luteal activity as suggested by volume and luteal cell size (Ogle et al., 1973; Buss \& Smith, 1975) may be indicative of extra-ovarian sources of progesterone production. Care should be taken, however, when comparing endocrine activity with CL morphology (volume) or appearance only. The contribution of the placenta to circulating levels of progesterone in maternal or fetal blood in elephants has never been assessed. During the first two-thirds ( $\sim 14$ months) of gestation a significant correlation was found between maternal and fetal plasma progesterone concentrations. Maternal progesterone values decreased during the last third of gestation while the fetal levels increased and there was no significant correlation (Fig. 3). This indicates a possible role of the placenta in progesterone secretion during the second half of gestation, or there could be fetal adrenal progesterone production.

Plotka et al. (1988) suggested that the length of the ovarian cycle in African elephants, based upon changes in serum progesterone, averaged $15.0 \pm 0.4$ weeks (luteal phase $9.2 \pm 0.2$ weeks and interluteal phase $5.8 \pm 0.4$ weeks). Serum progesterone concentration averaged $328 \mathrm{pg} / \mathrm{ml}$ and ranged from $<50$ to $933 \mathrm{pg} / \mathrm{ml}$ during the luteal phase (Plotka et al., 1988). Progesterone values were much higher during the luteal phase in the present study $(808 \cdot 2 \pm 44 \cdot 4 \mathrm{pg} / \mathrm{ml})$ with a smaller range. Results indicate a decline in plasma progesterone concentrations towards the end of the luteal phase and an increase with follicular development.

The 4 non-pregnant elephant cows with developing follicles in the late follicular growth phase had high plasma progesterone concentrations. It is, however, not possible to estimate the relative contribution that intrafollicular hormones make to those in peripheral plasma (McNatty et al., 1975). Hormonal concentrations in the follicular fluid were not measured in the present study. Intrafollicular steroids probably diffuse slowly out of follicular fluid into the ovarian vein (YoungLai \& Short, 1970). This seems to be the case for elephants; 2 of the cows had only a single follicle each and the other 2 cows had 2 and $3 \mathrm{CL}$ with small volumes $\left(2.00 \pm 0.50 \mathrm{~cm}^{3}\right)$ and follicles present in the ovaries, with high plasma progesterone concentrations.

McNeilly et al. (1983) indicated a considerable overlap between progesterone concentrations in pregnant and non-pregnant elephant cows with significantly higher values during pregnancy. This difference was not evident in the present study which showed progesterone concentrations to be high during the follicular phase of the ovarian cycle and that developing follicles probably secrete progesterone. This might explain the large variation in progesterone values measured in nonpregnant elephants, collected during different stages of the ovarian cycle.

Little is known about the production and metabolism of progesterone and the relative contribution of the uterus and placenta in the elephant and the rates of secretion of this steroid are not necessarily reflected in the circulating concentrations.

Financial support was provided by the University of Pretoria and The Council for Scientific and Industrial Research. 


\section{References}

Buss, I.O. \& Smith, N.S. (1966) Observations on reproduction and breeding behavior of the African elephant. J. Wildl. Mgmi 30, 375-388.

Craig, G.C. (1984) Foetal mass and date of conception in African elephants: a revised formula. S. Afr. J. Sci. 80, 512-516.

Hanks, J. \& Short, R.V. (1972) The formation and function of the corpus luteum in the African elephant, Loxodonta africana. J. Reprod. Fert. 29, 79-89.

Haresign, W., Foster, J.P., Haynes, N.B., Crighton, D.B. \& Lamming, G.E. (1975) Progesterone levels following treatment of seasonally anoestrous ewes with synthetic LH-releasing hormone. J. Reprod. Fert. 43, $269-279$.

Huggett, A.St.G. \& Widdas, W.F. (1951) The relationship between mammalian foetal weight and conception age. J. Physiol., Lond. 114, 306-317.

Laws, R.M. (1966) Age criteria for the African elephant, Loxodonta africana. E. Afr. Wildl. J. 4, 1-37.

Laws, R.M. \& Parker, I.S.C. (1968) Recent studies on elephant populations in East Africa. Symp. zool. Soc. Lond. 21, 319-359.

MeNatty, K.P., Hunter, W.M., McNeilly, A.S. \& Sawers, R.S. (1975) Changes in the concentration of pituitary and steroid hormones in follicular fluid of human Graafian follicles throughout the menstrual cycle. $J$. Endocr. 64, 555-571.

McNeilly, A.S., Martin, R.D., Hodges, J.K. \& Smuts, G.L. (1983) Blood concentrations of gonadotrophins, prolactin and gonadal steroids in males and in non-pregnant and pregnant female African elephants (Loxodonta africana). J. Reprod. Fert. 67, 113-120.

Ogle, T.F., Braach, H.H. \& Buss, I.O. (1973) Fine structure and progesterone concentration in the corpus luteum of the African elephant. Anat. Rec. 175, 707-724.

Perry, J.S. (1953) The reproduction of the African elephant (Loxodonta africana). Phil. Trans. R. Soc. B 237, 93-149.
Plotka, E.D., Seal, U.S., Schobert, E.E. \& Schmoller, G.C. (1975) Serum progesterone and estrogens in elephants. Endocrinology 97, 485-487.

Plotka, E.D., Seal, U.S., Zarembka, F.R., Simmons, L.G., Teare, A., Phillips, L.G., Hinshaw, K.C. \& Wood, D.G. (1988) Ovarian function in the elephant: luteinizing hormone and progesterone cycles in African and Asian elephants. Biol. Reprod. 38, 309314.

Short, R.V. (1966) Oestrous behavior, ovulation and the formation of the corpus luteum in the African elephant, Loxodonta africana. E. Afr. Wildl. J. 4, 56-68.

Short, R.V. \& Buss, I.O. (1965) Biochemical and histological observations on the corpora lutea of the African elephant, Loxodonta africana. J. Reprod. Fert. 9, 61-67.

Smith, N.S. \& Buss, I.O. (1975) Formation, function and persistence of the corpora lutea of the African elephant (Loxodonta africana). J. Mammal. 56, $30-43$.

Smith, J.G., Hanks, J. \& Short, R.V. (1969) Biochemical observations on the corpora lutea of the African elephant, Loxodonta africana. J. Reprod. Fert. 20, 111-117.

Van Aarde, R.J. (1985) Circulating progesterone and oestradiol- $17 \beta$ concentrations in cyclic Cape porcupines, Hystrix africaeaustralis. J. Reprod. Fert. 75, 583-591.

Walpole, R.E. \& Myers, R.H. (1985) Probability and Statistics for Engineers and Scientists, 3rd edn. Macmillan, New York.

YoungLai, E.V. \& Short, R.V. (1970) Pathways of steroid biosynthesis in the intact Graafian follicle of mares in oestrus. J. Endocr. 47, 321-333.

Received 10 August 1988 